\title{
Az intertemporális befektetői preferenciák változásainak hatása az európai tőzsdei vállalatok tőkekeresletére*
}

\author{
Schepp Zoltán - Ulbert József - Tóth-Pajor Ákos
}

\begin{abstract}
A tanulmányban az intertemporális befektetői preferenciák és a tökekereslet kapcsolatát vizsgáljuk az európai tözsdei vállalatok gyakorlatában. Arra a kérdésre keressük a választ, hogy az intertemporális befektetői preferenciák hogyan befolyásolták az európai vállalatok tőkekeresletét a 2004-2016-ig terjedő időszakban. A hozamelvárások és a vállalati tökekereslet kapcsolatának vizsgálata olyan makroszintű sokkok hatásaira világít rá, mint a recesszió, a kamatkörnyezet változása vagy a tökekockázati prémium változása a tökepiacokon. A kutatásunk fókuszába helyezett kérdés megválaszolása érdekében megbecsültük a vizsgált vállalatokra jellemző, implicit intertemporális diszkonttöbbletet, így meghatározva a befektetői intertemporális preferenciákat leíró, tőkeköltségen felüli addicionális diszkontrátát. Ezután a hozamelvárások és a tökekereslet kapcsolatát vizsgáltuk meg regressziós modellek segítségével. Megállapítottuk, hogy az európai tőzsdei vállalatok gyakorlatában a tökekereslet csökkenése és az ennek következtében kialakuló beruházási restrikció az intertemporális diszkonttöbblet növekedésére vezethetö vissza. Ha ugyanis a befektetök a tökepiacokon a rövid távú érdekeiket helyezik elötérbe és a vállalatok igazodnak a befektetök intertemporális preferenciáihoz, akkor az a hosszú távú tulajdonosi értékteremtés ellenében hat. Az intertemporális diszkonttöbblet növekedése a fentieken túl, illetve azokkal összefüggésben a monetáris politikai lazítások hatásait is késleltetheti.
\end{abstract}

\section{Journal of Economic Literature (JEL) kódok: G31, E22, E52}

Kulcsszavak: tőkekereslet, beruházási döntések, intertemporális preferenciák, intertemporális diszkonttöbblet, hiperbolikus diszkontálás

* A jelen kiadványban megjelenő írások a szerzők nézeteit tartalmazzák, ami nem feltétlenül egyezik a Magyar Nemzeti Bank hivatalos álláspontjával.

Schepp Zoltán a Pécsi Tudományegyetem Közgazdaságtudományi Karának egyetemi tanára.

E-mail: schepp@ktk.pte.hu

Ulbert József a Pécsi Tudományegyetem Közgazdaságtudományi Karának egyetemi docense.

E-mail: ulbert@ktk.pte.hu

Tóth-Pajor Ákos a Pécsi Tudományegyetem Közgazdaságtudományi Karának egyetemi tanársegéde.

E-mail: toth-pajor.akos@ktk.pte.hu

A kutatást az Emberi Erőforrások Minisztériumának Felsőoktatási Intézményi Kiválósági Programja finanszírozta, a Pécsi Tudományegyetem 4. tématerületi, „A hazai vállalatok szerepének növelése a nemzet újraiparosításában” programja keretében (szerződés száma: 20765-3/2018/FEKUTSTRAT).

A magyar nyelvű kézirat első változata 2020. március 5-én érkezett szerkesztőségünkbe.

DOI: http://doi.org/10.25201/HSZ.19.2.88106 


\section{Bevezetés}

A tanulmány célja az intertemporális befektetői preferenciák vállalati tőkekeresletre gyakorolt hatásainak vizsgálata az európai tőzsdei vállalatok gyakorlatában. A tanulmányban azt vizsgáljuk meg, hogy a kamatkörnyezetben bekövetkező változások és a tőkepiaci folyamatok hogyan befolyásolták a befektetők intertemporális preferenciáit, és ezzel milyen változásokat eredményeztek az európai vállalatok tőkekeresletében a 2004-2016-ig terjedő időszakban.

A vállalatok tőkekeresletét a vállalatok által megvalósított beruházások bekerülési költségeinek aggregátumaként értelmezhetjük. A tőkekeresletet így a vállalatok beruházási döntései alakítják. Az intertemporális befektetői preferenciák a tőkeköltség-csatornán keresztül befolyásolják a vállalatok beruházási döntéseit, ilyen módon közvetve a vállalatok tőkekeresletére is hatással vannak.

A sajáttőke-költséget az eszközárazás egyensúlyi alapmodelljében, a tőkepiaci eszközárazási modellben a kockázatmentes hozam, a vállalatok piaci kockázata, illetve a tőkekockázati prémium alakulása határozza meg. A sajáttőke-költségen keresztül nyomon követhetjük a kamatváltozások és a tőkepiaci folyamatok hatásait, amelyek a vállalatok makrokörnyezetének változásaira reagálnak.

A kutatás során a Blundell-Wignall - Roulet (2013) által alkalmazott, a vállalati tőkekereslet és a sajáttőke-költség kapcsolatát leíró modellkeretet bővítjük ki a Davies et al. (2014) és Miles (1993) munkája alapján meghatározható intertemporális diszkonttöbblettel, ami a tőkepiaci befektetők implicit intertemporális preferenciáit írja le. Davies et al. (2014) munkájával szemben az általunk használt eszközárazási modellben a kockázati prémium nem állandó, megengedjük a tőkekockázati prémium változását. Így esetünkben az intertemporális diszkonttöbblet mértékét a kamatkörnyezet változásán felül a tőkepiaci folyamatok is befolyásolhatják.

Kutatásunk rámutat, hogy az implicit intertemporális diszkonttöbblet növekedése a vállalati tőkekereslet csökkenését vetíti előre, így a monetáris politikai lazítások tőkekereslet-élénkítő hatásait is késleltetheti.

A tanulmányban elsőként a befektetői intertemporális preferenciák és a tőkekereslet kapcsolatát vizsgáló szakirodalmat tekintjük át, és megfogalmazzuk az ennek alapján fontosnak tartott, empirikusan tesztelhető kutatási kérdéseinket. Ezután leíró jelleggel bemutatjuk a vizsgált vállalati mintát és az ahhoz kapcsolódó leíró statisztikákat. Ezt követően kutatási kérdésenként bontva ismertetjük a kutatási kérdések megválaszolása során alkalmazott módszereket, és értékeljük a kutatási kérdésekhez kapcsolódó eredményeket. Végül az eredmények alapján levonjuk a következtetéseket. 


\section{A tőkepiaci befektetők intertemporális preferenciái}

Blundell-Wignall - Roulet (2013), Campbell et al. (2012) és Simmons-Süer (2016) megmutatja, hogy a tulajdonosi hozamelvárások és a vállalati tőkekereslet között fordított arányosság figyelhető meg. Ha nő a sajáttőke-költsége, az a vállalatok tőkekeresletének csökkenését jelzi elöre. Vörös (2020) a termelési volumen és a szervezeti tanulás kapcsolatát vizsgálva amellett érvel, hogy diszkrét esetben a hozamelvárások növekedése a nagyobb termelési volumen miatt keletkezett termelési tapasztalat jelenértékét csökkenti, így magas diszkontráta esetén a vállalatok kisebb termelési volument, alacsony diszkontráta esetén pedig nagyobb termelési volument választanak. Ily módon - a neoklasszikus beruházáselmélet alapvetéséből kiindulva, a termelési volumen és a tőkekereslet között pozitív kapcsolatot feltételezve - magasabb hozamelvárások esetén a vállalatok tőkekereslete ugyanúgy csökken.

Fazzari és munkatársai (1988) kimutatják, hogy az alacsony osztalékot fizető vállalatok azért forgatják vissza a profitjukat, mert számukra a külső források bevonása a belső források költségeihez képest relatíve költséges. A saját tőke és a kamatozó kölcsöntőke költségei között megfigyelhető különbség növekedése a tulajdonosi kifizetéseknek kedvez. Mankins és szerzőtársai (2017) arra mutatnak rá, hogy míg a 80 -as és 90 -es években a tőke szűkös erőforrás volt, addig napjainkban a nagy mennyiségű, olcsó tőke keres profitábilis beruházási lehetőségeket. A döntéshozók által meghatározott küszöbértékek nem tükrözik a tőkeköltséget, ami sokszor a beruházások elutasításához vezet.

Simmons-Süer (2018) szerint a tőzsdei vállalatok esetében megfigyelhetünk olyan időszakokat, amelyekben a vállalatok alacsony tőkekereslete sem a kamatkörnyezetnek, sem a növekedési kilátásoknak nem tulajdonítható. Ezekben az időszakokban a hozamelvárások nem tükrözik a tőkeköltséget, ami Miller-Modigliani irrelevanciahipotézisét is cáfolja. Davies és szerzőtársai (2014) levezetik, hogy a tőkepiacokon a rövid távú befektetői érdekek a tőkeköltség-csatornán keresztül a beruházások viszszaesését eredményezhetik, és beruházási restrikciót okozhatnak. A sajáttőke-költség és a beruházások között negatív kapcsolat figyelhető meg, így, ha nőnek a tulajdonosi hozamelvárások, az a tőkeállomány bővülési ütemének csökkenésével jár.

Elsőként Miles (1993), majd Davies és társai (2014) találtak bizonyítékot a rövid távú befektetői érdekek érvényesülésére a tőkepiacokon, és rámutattak arra, hogy a rövid távú befektetői szemléletmód hosszabb távon tulajdonosi értéket rombol. Amennyiben a tőzsdei vállalatok a rövid távú befektetői érdekeket szolgálják ki a tőkepiacokon, úgy a negyedéves jelentésekre koncentrálnak, és a tulajdonosi kifizetéseket részesítik előnyben, ezzel növelve a befektetésből rövid távon realizálható hozamokat. Stein (1989) amellett érvel, hogy a menedzserek olyan beruházásokat preferálnak, amelyek rövid távon növelik az eredményességet. Ezt a piac azonnal lereagálja és beárazza. A rövid távú befektetői érdekek elsődlegessége miatt a rövid 
és hosszú táv közötti mérlegelések egyensúlya felborul (Martin 2015, Summers 2017, Favaro 2014, Mauboussin - Rappaport 2016).

Asker és társai (2014) amellett érvelnek, hogy a tőzsdei vállalatokkal szemben sokkal nagyobb mértékben érvényesülnek a rövid távú befektetői érdekek, mint a nem tőzsdei vállalatokkal szemben. Feldman és szerzőtársai (2018) arról írnak, hogy a tőkepiacok megkönnyítik a fedezet nélküli, kutatás-fejlesztésbe irányuló beruházásokat. Hackbarth és szerzőtársai (2018) szerint, ha a vállalatok kiszolgálják a befektetők rövid távú érdekeit, akkor az költségesebbé teszi a hosszú távú értékteremtést. A tulajdonosok az egyensúlyt keresik a rövid távon realizálható pénzáramok és a hosszú távon realizálható pénzáramok között.

A szakirodalom tehát egyértelmúen állást foglal amellett, hogy a döntéshozók intertemporális preferenciáit sok esetben nem ragadhatjuk meg az exponenciális diszkontálás szabályrendszerének keretei között, konstans diszkontrátát feltételezve. Az intertemporális preferenciák nem stacioner jellege és időbeli inkonzisztenciája időben változó diszkontráták, vagy a hiperbolikus diszkontálás eszközrendszerének használatával vehetők figyelembe (Janssens et al. 2017). Ezért jelen tanulmányban a befektetők intertemporális preferenciáinak vizsgálatára és az intertemporális döntések modellezésére a hiperbolikus diszkontálás módszerét alkalmazzuk, ami lehetővé teszi a rövid távú gondolkodás hatásainak vizsgálatainkba történő bevonását.

Phelps és Pollak (1968) ezt a módszert a generációk közötti intertemporális döntések modellezésére alkalmazta először, ahol megmutatták, hogy a döntéshozók nagyobb súllyal veszik figyelembe a saját generációjuk jólétét, mint a jövőbeli generációk jólétét. Laibson (1997) amellett érvel, hogy a döntéshozók saját jövőbeli lehetőségeiket korlátozzák, ha nagyobb súllyal veszik figyelembe a rövid távú kimeneteket. Rasmusen (2008) arról ír, hogy a hiperbolikus diszkontálás lényege a relatív időkezelés, és levezeti a helyettesítés határrátáját a különböző függvényformák eseteiben. Bölcskei (2009) is rámutat, hogy az intertemporális preferenciák sokszor a jelen felé torzítanak. A döntéshozók a rövid távú érdekeiket helyezik előtérbe. Neszveda-Dezső (2012) is amellett érvel, hogy hiperbolikus diszkontálás segítségével az intertemporális preferenciák jobban leírhatók. A tőkepiacokon a befektetők intertemporális preferenciáinak modellezésére Davies és szerzőtársai (2014) és Miles (1993) is hasonló diszkontfüggvényeket használnak.

A befektetők intertemporális preferenciáit Davies és szerzőtársai (2014) munkáját követve kvázi-hiperbolikus diszkontfüggvényekkel modellezhetjük. A szerzőket a hiperbolikus diszkontálás alkalmazására a rövid távú befektetői szemlélet bemutatása motiválta. Az intertemporális preferenciák a diszkontfüggvényben egy intertemporális preferenciákat leíró diszkontfaktorként jelennek meg, amit a (1) egyenletben az $x$ változó jelöl. Az intertemporális diszkonttöbbletet egy addicionális, intertemporális 
preferenciákat leíró diszkontrátaként értelmezhetjük, így az x intertemporális preferenciákat leíró diszkontfaktor az intertemporális diszkonttöbblet függvénye.

Ha $x<1$, akkor a döntéshozóra rövid távú szemlélet jellemző, mivel nagyobb súlylyal veszi figyelembe a rövid távon realizálható pénzáramokat, és a tőkeköltségnél nagyobb hozamelvárásokat fogalmaz meg.

Ha $x>1$, akkor a döntéshozóra hosszú távú szemléletmód jellemző, mert a hosszú távon realizálható pénzáramokat veszi nagyobb súllyal figyelembe, és a tőkeköltségnél kisebb hozamelvárásokat fogalmaz meg.

$$
D_{I}(T)=\frac{x^{T}}{(1+r)^{T}}
$$

ahol $D_{l}(T)$ a döntéshozó intertemporális preferenciáit leíró diszkontfüggvényt, $r$ a tőkeköltséget, $T$ a lejáratot és $x$ az intertemporális preferenciákat leíró diszkontfaktort jelöli.

Davies et al. (2014) empirikus vizsgálatokkal is bizonyítja a rövid távú érdekek érvényesülését az intertemporális tőkeallokációs döntések vonatkozásában. Az 1995től 2004-ig terjedő időszakban Anglia és az Egyesült Államok tőkepiacait vizsgálva Davies et al. (2014) szerint az intertemporális preferenciákat leíró diszkontfaktor mértéke $x=0,938$. Az intertemporális diszkonttöbbletet így a (2) egyenlet alapján határozhatjuk meg.

$$
i t p=x^{-1}-1,
$$

ahol itp az intertemporális preferenciákat leíró diszkonttöbblet.

A (2) egyenlet alapján az implicit, intertemporális diszkonttöbblet 1995 és 2004 között átlagosan 6,6 százalék volt. A befektetők ekkora addicionális hozamot vártak el a vállalatok tőkeköltsége felett.

Davies és munkatársai (2014) továbbá levezetik, hogy a befektetői, rövid távú szemléletmód a beruházások helyett a tulajdonosi kifizetések irányába mozdítja a vállalati tőkeallokációt. Ezek a vizsgálatok megmutatták, hogy a tőkepiacokon a döntéshozók intertemporális preferenciái nem stacionáriusak, a befektetők a rövid távú érdekeiket helyezik előtérbe az intertemporális tőkeallokációs döntéseik során, ami a tőkeköltség csatornán keresztül a vállalati beruházások visszafogását eredményezi. Az implicit, intertemporális preferenciák és a tőkekereslet kapcsolatának vizsgálata új szempontokra mutat rá a hozamelvárások és a beruházások kapcsolatát elemző tanulmányokban.

A szakirodalom áttekintését követően két, empirikusan tesztelhető kutatási kérdést vizsgálunk meg. Egyrészt arra keressük a választ, hogy hogyan változott az 
intertemporális diszkonttöbblet a 2004-2016 közötti időszakban. Másrészt pedig arra, hogy ez a változás milyen hatással volt a vállalatok tőkekeresletére, és hogyan befolyásolta a monetáris politikai intézkedések gazdaságélénkítő hatását. Előzetes várakozásaink alapján az alábbi állításokat fogalmaztuk meg:

1. Az intertemporális diszkonttöbblet a vizsgált időszakban (2004-2016) növekedett.

2. Növekedése a tulajdonosi hosszú távú értékteremtési törekvéseket a beruházási restrikción keresztül háttérbe szorította, ezzel a monetáris politikai lazítások tőkekereslet-élénkítő hatásait is késleltethette.

\section{Minta és leíró statisztikák}

A kulcsváltozók kiszámításához szükséges beszámoló adatokat a Refinitiv adatbázisából gyűjtöttük össze a 2004-2017-ig terjedő időszakra vonatkozóan. Az így létrehozott paneladatbázis Európában bejegyzett tőzsdei vállalatok mérleg-, eredménykimutatás- és cash-flow-kimutatás adatait tartalmazza. A vállalati beszámolók adatain felül az adatállomány piaci információkat is tartalmaz. Az adatok az intertemporális diszkonttöbblet becslését 2004-2016 között tették lehetővé, így a leíró statisztikákat is erre az időszakra közöljük.

A minta tisztítása:

- kizárásra kerültek a negatív saját tőkével rendelkező, és

- a zérus árbevétellel rendelkező vállalatok,

- követelmény volt továbbá, hogy csak a vizsgálat teljes időszakában tőzsdén jegyzett vállalatok maradjanak a mintában,

- a 27 országbeli vállalati beszámolók adatait és piaci információit a Refinitiv által számított EUR értéken szerepeltetjük.

- a pénzügyi szektort, a közszolgáltatókat, valamint az ingatlanszektort a global industry standards (GICS) besorolás alapján kizártuk a mintából a számviteli szabályozások különbözősége miatt, így 55 különböző iparág vállalatai szerepelnek a mintában.

Átlagosan 30 éve tőzsdén jegyzett vállalatok alkotják az empirikus kutatás alapjául szolgáló adatállományt, így a minta érett tőzsdei vállalatok vizsgálatát teszi lehetővé. A Refinitiv adatbázisában 2984 Európában bejegyzett tőzsdei vállalat szerepelt, amelyek esetében a kulcsváltozók kiszámításához szükséges adatok rendelkezésre álltak. A szelekciós kritériumok szerinti szűrést követően a kutatás során összesen 14 üzleti évet vizsgáltunk és 527 tőzsdei vállalat maradt a mintában. Ez a rendelkezésre álló vállalatok 17,66 százalékát jelenti. 
A kulcsváltozók tekintetében az extrém értékeket az interkvartilis távolság módszerével szürtük ki. Amennyiben a mutatószám adott értéke az interkvartilis távolság 3-szorosánál nagyobb távolságra helyezkedett el a 25. és a 75. percentilishez viszonyítva, úgy az értékeket az 5. és 95. percentilishez tartozó értékekkel helyettesítettük (Hastings et al. 1947, Dixon 1960, Tukey 1977). A minta megfelelően reprezentálja Európa tőkepiacait, így alkalmas a tőkekereslet és az intertemporális preferenciák kapcsolatának vizsgálatára.

Az 1. táblázatban a vállalati tőkekereslet és a sajáttőke-költség közötti kapcsolatot vizsgáló modellekben és az implicit, intertemporális diszkonttöbblet becslésénél használt változók számítási módját mutatjuk be. A tőkekereslet (I) mértékét a bruttó tőkekiadások (CAPEX) definiálja, amely a tárgyieszköz-beszerzések és az immateriális javakba történő beruházások összegeként kerül meghatározásra a tőzsdei vállalatok cash-flow-kimutatásában. A tőkereslet így a tárgyieszköz-beruházások és az immateriális javakba történő beruházások bekerülési költségeként értelmezhető.

Hasonlóan Blundell-Wignall - Roulet (2013) munkájához a tőkekeresletet az árbevétel $(S)$ arányában vizsgáljuk, így összehasonlíthatóvá vállnak a különböző méretű vállalatok.

\section{1. táblázat}

\section{A kulcsváltozók definíciói}

\begin{tabular}{|c|c|c|}
\hline Változó & Jelölés & Számítási mód \\
\hline Tőkekereslet az árbevétel arányában & $\mathrm{I}_{\mathrm{i}, \mathrm{t}} / \mathrm{S}_{\mathrm{i}, \mathrm{t}}$ & $\begin{array}{l}\text { Bruttó tőkekiadások (CAPEX) })_{i, t} \\
\text { Az értékesítés nettó árbevétele } e_{i, t}\end{array}$ \\
\hline Tőkeintenzitás & $\mathrm{K}_{\mathrm{i}, \mathrm{t}} / \mathrm{S}_{\mathrm{i}, \mathrm{t}}$ & $\begin{array}{c}\left(\text { Immateriális javak } k_{i, t}+\text { Tárgyi eszközök } k_{i, t}\right) \\
\text { Az értékesítés nettó árbevétele } e_{i, t}\end{array}$ \\
\hline \multirow[t]{4}{*}{ Sajáttőke-költség } & $\mathrm{COE}_{\mathrm{i}, \mathrm{t}}$ & $r_{f, t}+\beta_{i} E R P_{i, t}$ \\
\hline & $r_{f, t}$ & 10 éves EKB zéró kupon hozam \\
\hline & $\beta_{i}$ & CAPM Béta (Refinitiv által becsült) \\
\hline & $\mathrm{ERP}_{\mathrm{i}, \mathrm{t}}$ & Tőkekockázati prémium \\
\hline Egy részvényre jutó osztalék (EUR) & $\mathrm{DPS}_{\mathrm{i}, \mathrm{t}}$ & Fizetett osztalék ${ }_{\mathrm{i}, \mathrm{t}}$ / Részvények száma $\mathrm{i}_{\mathrm{i}, \mathrm{t}}$ \\
\hline Egy részvényre jutó adózott eredmény (EUR) & $\mathrm{EPS}_{\mathrm{i}, \mathrm{t}}$ & Adózott eredmény $_{\mathrm{i}, \mathrm{t}} /$ Részvények száma $_{\mathrm{i}, \mathrm{t}}$ \\
\hline
\end{tabular}

A hosszú távon megcélzott müködéshez szükséges tőkeállományt a vállalatok kibocsátása határozza meg. Hosszú távon a vállalat kibocsátása és tőkeállománya arányos egymással. Ezt az arányt nevezzük tőkeintenzitásnak. A tőkeintenzitás azt méri, hogy egységnyi árbevétel $(S)$ megtermeléséhez a vállalatnak mennyi tőkére van szüksége. A tőkeintenzitás meghatározza a hosszú távon megcélzott működéshez szükséges tőkeállományt. A tőkeállományt $(K)$ az immateriális javak és a tárgyi eszközök összegeként határozzuk meg. A sajáttőke-költségét (COE) a 10 éves EKB 
zéró kupon hozam $\left(r_{f}\right)$ és a vállalatokra jellemző kockázati prémium összegeként definiáljuk. Azért választottuk a 10 éves EKB zéró kupon hozamot, mert a mintában szereplő országok között legnagyobb arányban az eurozóna országok vannak jelen. Így az EKB zéró kupon hozam jól reprezentálja a mintában szereplő országok kockázatmentes hozamát.

A kockázati prémiumot a vállalat székhelye szerinti ország tőkepiacán megfigyelhető, Damodaran (2019) munkája alapján becsült, implicit tőkekockázati prémium $(E R P)$ és a vállalatra jellemző piaci kockázat $\left(\beta_{i}\right)$ szorzataként határoztuk meg. A piaci kockázat mérőszámaként a Refinitiv által becsült vállalatokra jellemző bétákat használtuk. A definíció szerint a sajáttőke-költség változását a kamatkörnyezet és a tőkepiaci kockázati prémium változása eredményezi. $A$ vállalatok részvényhozamai és a piaci hozam közötti együttmozgás intenzitását a vizsgált időszakban állandónak feltételezzük. Így a saját tőke költségének változásán keresztül a makroszintű sokkok hatásait követhetjük nyomon.

A részvényárat $(P)$, az egy részvényre jutó adózott eredményt (EPS) és az egy részvényre jutó osztalékot (DPS) euróban szerepeltetjük. Az üzleti éveket $t$-vel, a vállalatokat $i$-vel indexáljuk.

\section{2. táblázat}

A kulcsváltozók leíró statisztikái a teljes minta alapján

\begin{tabular}{c|c|c|c|c|c|c} 
Változó & Átlag & Szórás & Minimum & Medián & Maximum & $\begin{array}{c}\text { Megfigyelések } \\
\text { száma }\end{array}$ \\
\hline $\mathrm{I}_{\mathrm{i}, \mathrm{t}} / \mathrm{S}_{\mathrm{i}, \mathrm{t}}$ & 0,058 & 0,052 & 0 & 0,041 & 0,224 & 6851 \\
\hline $\mathrm{K}_{\mathrm{i}, \mathrm{t}} / \mathrm{S}_{\mathrm{i}, \mathrm{t}}$ & 0,353 & 0,316 & 0,005 & 0,247 & 1,317 & 6851 \\
\hline $\mathrm{COE}_{\mathrm{i}, \mathrm{t}}$ & 0,077 & 0,024 & 0,004 & 0,076 & 0,184 & 6851 \\
\hline $\mathrm{r}_{\mathrm{f}, \mathrm{t}}$ & 0,032 & 0,012 & 0,009 & 0,037 & 0,044 & 6851 \\
\hline$\beta_{\mathrm{i}}$ & 0,81 & 0,392 & $-0,082$ & 0,809 & 2,312 & 6851 \\
\hline $\mathrm{ERP}_{\mathrm{i}, \mathrm{t}}$ & 0,056 & 0,011 & 0,045 & 0,05 & 0,2 & 6851 \\
\hline $\mathrm{DPS}_{\mathrm{i}, \mathrm{t}}$ & 0,578 & 0,809 & 0 & 0,263 & 4,077 & 6851 \\
\hline $\mathrm{EPS}_{\mathrm{i}, \mathrm{t}}$ & 1,221 & 1,9 & $-4,97$ & 0,569 & 9,699 & 6851 \\
\hline $\mathrm{P}_{\mathrm{i}, \mathrm{t}}$ & 22,451 & 30,288 & 0,01 & 10,54 & 170,309 & 6851 \\
\hline
\end{tabular}

A 2. táblázat a kulcsváltozók leíró statisztikáit szemlélteti a teljes minta alapján. A vállalatokról elmondható, hogy a 2004-2016 közötti időszakban évente átlagosan 5,8 százalékkal bővítették a tőkeállományukat, az árbevétel arányában. A tőkeintenzitást tekintve egységnyi árbevétel megtermeléséhez átlagosan 0,353 egység tőkére volt szükségük. A piaci kockázatot mérő béta értéke átlagosan 0,81. A sajáttőke-költség 7,7 százalék körül mozog, míg a tőkekockázati prémium átlagosan 5,6 százalék. 
Az egy részvényre jutó adózott eredmény átlaga 1,22 EUR. Az egy részvényre jutó osztalék átlagos értéke 0,578 EUR. A 10 éves EKB zéró kupon hozam átlagosan 3,2 százalék volt a vizsgált üzleti években.

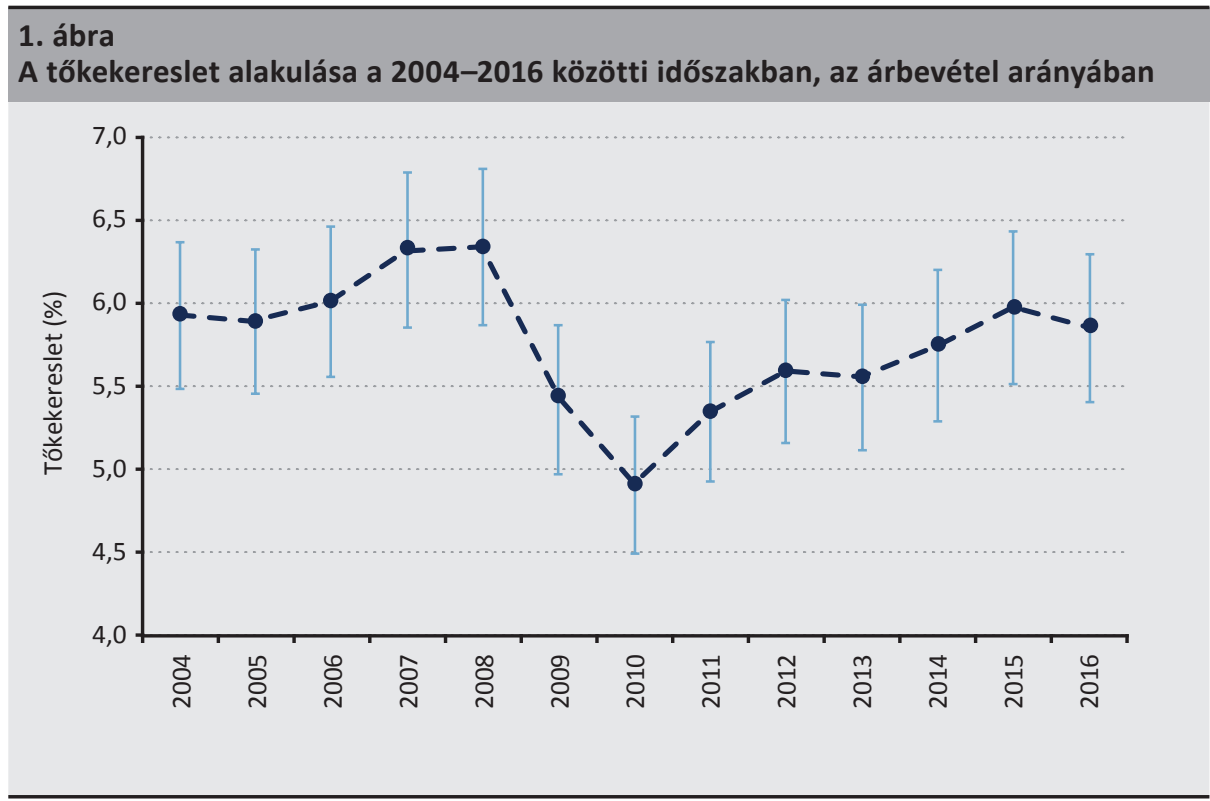

Az 1. ábrán a tőkekereslet üzleti évek szerinti átlagának alakulása látható a vizsgált időszakban, az árbevétel arányában. Míg 2007-ben a vállalatok átlagosan a tőkeállományukat 6,3 százalékkal bővítették, addig a válságévek folyamán a tőkeakkumulációs ráta 5 százalék alá esett vissza, majd az alacsony kamatkörnyezetben 5,8 százalékra kapaszkodott vissza 2016-ra. Duchin et al. (2010) érvel amellett, hogy a beruházások visszaesését a válság miatt megfigyelhető külső forráskínálati sokk eredményezte. A 2009-2010-es beruházási sokk nagy visszaesést eredményezett a tőkeállomány bővítésének ütemében.

Az intertemporális preferenciák vizsgálatához a kockázatmentes hozamok trendje, a tőkekockázati prémium trendje, valamint a saját tőke költségének változása hordoz fontos információkat. A 2. ábrán jól látható, hogy a 10 éves EKB zéró kupon hozam mintaátlaga egészen 2011-ig 3-4,5 százalék között ingadozott. A 2011-es üzleti évet követően az eurozóna adósságválságának lecsengésével párhuzamosan a 10 éves EKB zéró kupon hozam csökkenését figyelhetjük meg. A vállalatok székhelyei szerinti tőkepiacokon megfigyelhető Damodaran (2019) munkája alapján becsült, implicit tőkekockázati prémiumot vizsgálva látható, hogy a válságot követően a tőkekockázati prémium mintaátlaga 5 -ről 7 százalékra növekedett. A kockázatmentes 
hozam és a tőkekockázati prémium eredőjeként a sajáttőke-költség mintaátlaga csak 2014-re csökkent le. A 2. ábra jól összefoglalja, hogy a kamatkörnyezet változása és a tőkepiacon megfigyelhető folyamatok milyen hatással voltak az európai tőzsdei vállalatok sajáttőke-költségére.

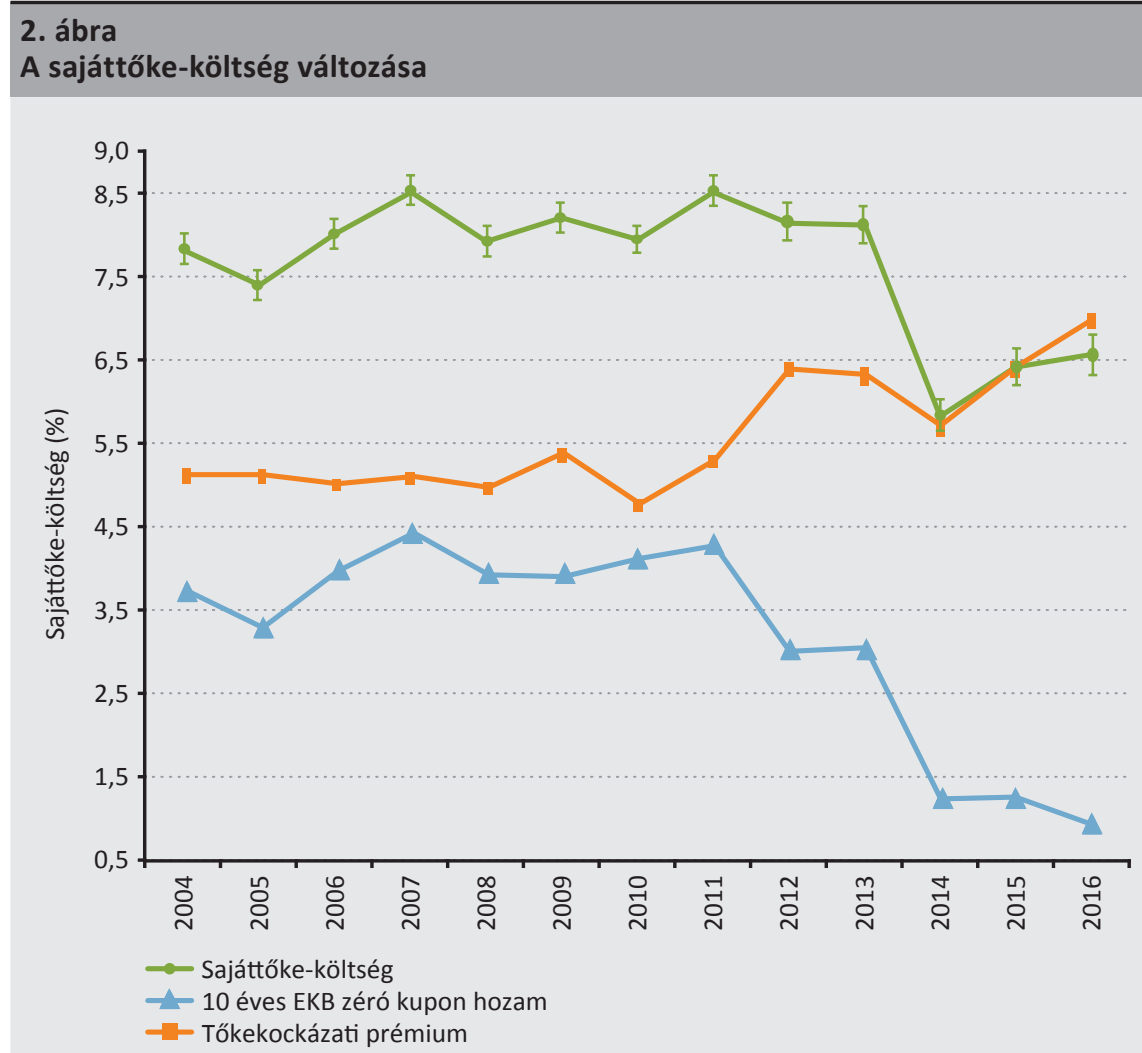

\section{Az intertemporális diszkonttöbblet változása a 2004-2016 közötti időszakban}

Az implicit, intertemporális diszkonttöbblet becslését Davies et al. (2014) munkájára alapozzuk. A szerzők egy eszközárazási modellben alkalmaznak kvázi-hiperbolikus diszkontfüggvényeket annak érdekében, hogy megbecsüljék az intertemporális diszkonttöbblet mértékét. $A$ becslések során alkalmazott eszközárazási modellt egy intertemporális preferenciákat leíró diszkonttényezővel egészítik ki.

Az általunk használt eszközárazási modell annyiban különbözik Davies et al. (2014) modelljétől, hogy a sajáttőke-költségét tekintve a vállalatokra jellemző kockázati 
prémiumot az implicit tőkekockázati prémiumok és a vállalatra jellemző béta szorzataként határoztuk meg. A sajáttőke-költség ilyen módon történő definiálása a tőkepiaci eszközárazási modellre (CAPM) épül. A piaci portfólió és a vállalati részvények együttmozgását a vizsgált időszakban állandónak tekintettük. Így, ellentétben Davies et al. (2014) munkájával, esetünkben a sajáttőke-költséget nem csak a kamatváltozás, de a kockázati prémium időbeli változása eredményezi, míg a vállalatok közötti heterogenitást csak a piaci kockázat befolyásolja. Davies et al. (2014) munkájával szemben az általunk alkalmazott eszközárazási modellben a kockázati prémium változhat a vizsgált időszakban, így az intertemporális diszkonttöbblet mértékét a kamatkörnyezet változásán túl a tőkepiaci folyamatok is befolyásolhatják. Az intertemporális preferenciák becsléséhez alkalmazható eszközárazási modellt Davies et al. (2014) munkája alapján a (3) egyenlet segítségével határozhatjuk meg:

$$
P_{i, t}=\sum_{j=1}^{N} \frac{E_{t}\left(D P S_{i, t+j}\right) x_{t}^{j}}{\left(1+C O E_{i, t+j}\right)^{j}}+\frac{E_{t}\left(P_{i, t+N}\right) x_{t}^{N}}{\left(1+C O E_{i, t+N}\right)^{N}},
$$

ahol $i$-vel a vállalatokat, $j$-vel a tartási periódus éveit, $t$-vel az üzleti éveket indexáljuk, valamint $P_{i, t}$ a részvényárat, $N$ a tartási periódust, $D P S_{i, t}$ az egy részvényre jutó osztalékot, $C O E_{i, t}=r_{f, t}+\beta_{i} E R P_{i, t}$ a saját tőke költségét és $x_{t}$ az adott évre vonatkozó implicit, intertemporális diszkonttényezőt jelöli.

A (3) egyenletben szereplő várható értékeket tekintve Wickens (1982) amellett érvel, hogy a várható értékek megegyeznek a realizált érték és az előrejelzési hiba különbségével. Ebben az esetben az $N$ periódussal későbbi részvényár $t$ időpontbeli várható értékét a (4) egyenlet segítségével határozhatjuk meg.

$$
E_{t}\left(P_{i, t+N}\right)=P_{i, t+N}-U_{i, t+N},
$$

ahol $U_{i, t+N}$ az előrejelzési hibát jelöli.

Ebben az esetben az $x$ paraméter becslése olyan instrumentális módszerekkel történhet, ahol az instrumentumok korrelálnak a $P_{i, t+N}$ részvényárral, de az előrejelzési hibával nem. A (3) egyenletben az x paraméter becslése így nem lineáris, két lépcsős legkisebb négyzetek módszerével lehetséges. Instrumentumokként az egy részvényre jutó adózott eredmény, az egy részvényre jutó osztalék késleltetett értékei alkalmazhatók a jövőbeli egy részvényre jutó osztalék és a jövőbeli részvényárak esetében. Az $x$ intertemporális preferenciákat leíró diszkontfaktor, így minden üzleti évre megbecsülhető, és ezzel nyomon követhető a befektetők intertemporális preferenciáinak változása a tőkepiacokon. Neszveda - Dezső (2012) amellett érvel, hogy a kvázi hiperbolikus diszkontfüggvények hosszú távon nagyságrendekkel eltérnek az általánosított hiperbolikus diszkontálás eredményeitől. Ennek okán az általunk felépített modellben az $N$ tartási periódusnak 5 évet határoztunk meg, kivéve azokban az években, amikor már nem volt elég megfigyelés az 5 éves tartási periódushoz. Ennek megfelelően 2012 után, minden évben eggyel rövidült a tartási 
periódus. Így modellünk egy középtávú befektetési időhorizontot vizsgál. A 2017es üzleti évre a rendelkezésre álló adatok alapján már nem lehet megbecsülni az intertemporális diszkonttöbbletet.

A 3. ábra az implicit intertemporális diszkonttöbblet alakulását követi nyomon a 2004-2016-os időszakban. A (3) egyenlet alapján ismertetett eszközárazási modell segítségével először az $x$ intertemporális preferenciákat leíró diszkontfaktort becsültük meg, majd ebből fejeztük ki az implicit intertemporális diszkonttöbbletet a (2) egyenletben ismertetett képlet alapján. Az $x$ paramétert az előrejelzési hibák miatt nemlineáris, kétlépcsős legkisebb négyzetek módszerével becsültük meg minden üzleti évre.

A keretmetszeti regressziós modellek esetében az $R^{2} 72$ és 95 százalék között ingadozik. A megbecsült intertemporális diszkontfaktor minden évben 1 százalékos szinten szignifikáns. A paraméterbecslést követően Wald-próba segítségével megvizsgáltuk, hogy az intertemporális diszkontfaktor szignifikánsan különbözik-e 1-től, hiszen ha $x=1$, akkor az implicit intertemporális diszkonttöbblet 0 . A Wald-próbák eredményei minden évben szignifikáns eltéréseket mutattak. A Hansen-J-statisztikák alapján egyik esetben sem vetettük el a null-hipotézist, miszerint az alkalmazott instrumentum-halmaz megfelelő. A 3. ábrán a pontbecslések mellett a White (1980) munkáján alapuló, heteroszkedaszticitást is számításba vevő standard hibák alapján számolt 95 százalékos konfidencia-intervallumot jelenítjük meg.

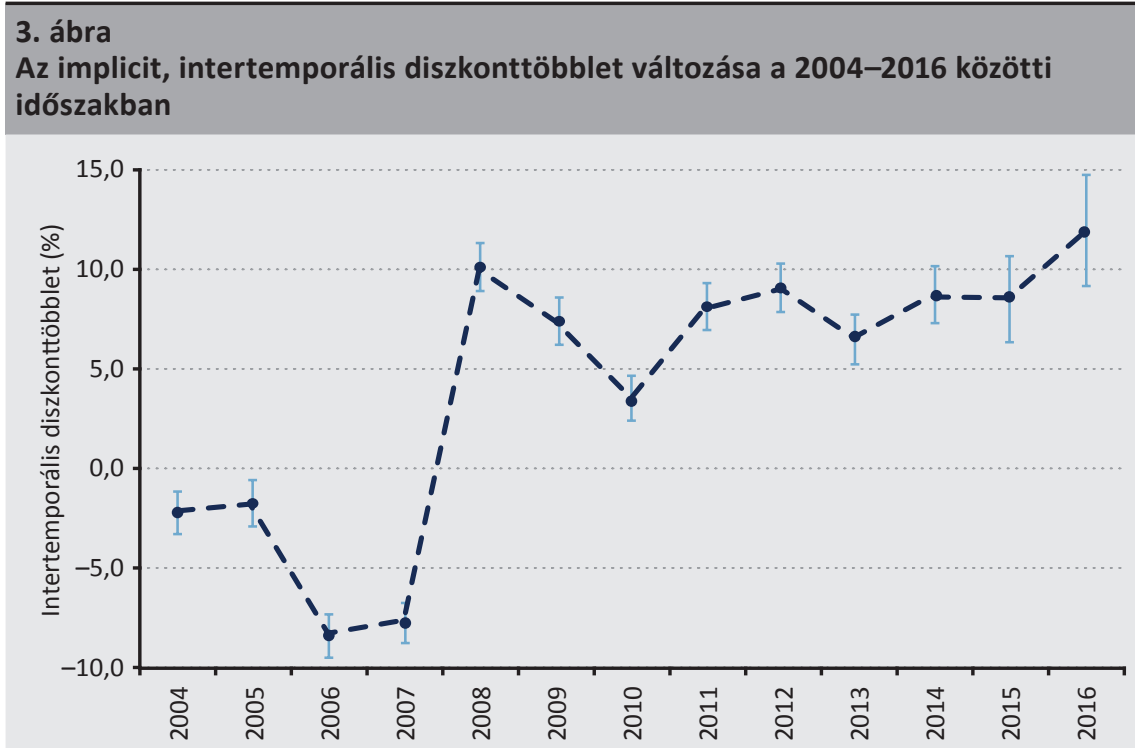


A 3. ábra alapján látható, hogy 2008 előtt az implicit, intertemporális diszkonttöbblet értéke negatív volt. Így ebben az időszakban a befektetők hozamelvárásai a tőkepiacon átlagosan a sajáttőke-költség alatt voltak. Ez arra utal, hogy a befektetőket 2008 előtt hosszú távú szemléletmód jellemezte, könnyebben cserélték el a jelenbeli jövedelmüket egy jövőbeli hozamígéretre. A legnagyobb negatív intertemporális diszkonttöbblet 2006-ban figyelhető meg, amikor a befektetók átlagosan 8,4 százalékkal alacsonyabb hozamelvárásokat támasztottak a sajáttőke-költséghez képest. 2008-tól az intertemporális diszkonttöbblet értéke pozitív, ami arra utal, hogy a befektetők hozamelvárásai átlagosan a sajáttőke-költség fölé kerültek. Ebben az esetben a befektetők a rövid távú érdekeiket helyezik előtérbe a tőkepiacokon, ezért nehezebben cserélik el a jelenbeli jövedelmüket egy jövőbeli hozamígéretre. 2008-ban az intertemporális diszkonttöbblet 10,1 százalék volt. Átlagosan ennyivel magasabb hozamelvárást fogalmaztak meg a befektetők a tőkepiacokon a tőkeköltség felett.

\section{Az intertemporális diszkonttöbblet növekedésének hatása az európai tőzsdei vállalatok tőkekeresletére}

A befektetői hozamelvárások a tőkeköltség-csatornán keresztül a vállalatok tőkekeresletére is hatnak, mivel a hozamelvárások a vállalatok szemszögéből vizsgálódva tőkeköltségként értelmezhetők. Az implicit, intertemporális diszkonttöbblet növekedése a beruházási döntések során alkalmazott diszkontráta növelésén keresztül csökkentheti a vállalatok tőkekeresletét.

Az intertemporális diszkonttöbblet becslését követően megvizsgáltuk az intertemporális preferenciák tőkekeresletre gyakorolt hatásait. Blundell-Wignall - Roulet (2013) amellett érvelnek, hogy a hozamelvárások és a vállalatok tőkekereslete között fordított arányosság figyelhető meg. Megmutatják továbbá, hogy a saját tőke költsége és a tőkekereslet között negatív kapcsolat van. A sajáttőke-költség jó viszonyítási pont a hozamelvárások tekintetében, de a döntéshozók általában ettől eltérő küszöbértékeket alkalmaznak a beruházási döntések során, amit a sajáttőke-költség alkalmazása kevésbé jól ragad meg. Ezért tartjuk fontosnak az implicit, intertemporális diszkonttöbblet vizsgálatát, amely a küszöbértékek és a sajáttőke-költség közötti különbségeket ragadja meg.

Az intertemporális diszkonttöbblet-növekedés hatásainak vizsgálata során Blundell-Wignall - Roulet (2013) modelljéhez hasonló modellt alkalmazunk, amelyet az implicit intertemporális diszkonttöbblet és az intertemporális preferenciákat leíró diszkontfaktor hatásait figyelembe véve bővítünk ki. Modellünk segítségével jobban megragadhatjuk a befektetők hozamelvárásait. 
Az alapmodellt az (5) egyenlet szemlélteti.

$$
\frac{I_{i, t}}{S_{i, t}}=\beta_{1} \operatorname{COE}_{i, t-1}+\beta_{2} \frac{K_{i, t}}{S_{i, t}}+\mu_{i}+\varepsilon_{i, t},
$$

ahol $I_{i, t} / S_{i, t}$ az egységnyi árbevételre jutó tőkekeresletet, $C O E_{i, t-1}$ a saját tőke költségét, $K_{i, t} / S_{i, t}$ a tőkeintenzitást, $\mu_{i}$ az egyedhatásokat, $\varepsilon_{i, t}$ a hibatagot és $\beta$ a regressziós modell paramétereit jelöli.

Az alapmodellbe további magyarázóváltozókként az intertemporális preferenciákat leíró diszkontfaktor $(x)$ és az intertemporális diszkonttöbblet (itp) trendjét vonjuk be. A két különböző trendváltozó használatával lehetőségünk nyílik megmutatni, hogy biztosan az intertemporális preferenciák hatásait ragadjuk meg, és nem csak az idő múlása jelenik meg a trendváltozókban. Előzetesen arra számítunk, hogy a tőkekereslet és a diszkontfaktor trendje között pozitív kapcsolatot, míg az intertemporális diszkonttöbblet esetében negatív kapcsolatot figyelhetünk meg. A modellekbe a trendváltozók késleltetett értékeit vonjuk be, mert a trendváltozók prediktív tulajdonságait szeretnénk vizsgálni.

A (6) egyenletben a modellt az intertemporális preferenciákat leíró diszkontfaktor trendjével egészítettük ki.

$$
\frac{I_{i, t}}{S_{i, t}}=\beta_{1} x_{t-1}+\beta_{2} \operatorname{COE}_{i, t-1}+\beta_{3} \frac{K_{i, t}}{S_{i, t}}+\mu_{i}+\varepsilon_{i, t},
$$

ahol $x_{t-1}$ az intertemporális preferenciákat leíró diszkontfaktor késleltetett trendjét jelöli.

A (7) egyenletben az alapmodellbe az implicit intertemporális preferenciákat leíró diszkonttöbblet trendjét vonjuk be magyarázó változóként.

$$
\frac{I_{i, t}}{S_{i, t}}=\beta_{1} i t p_{t-1}+\beta_{2} \operatorname{COE}_{i, t-1}+\beta_{3} \frac{K_{i, t}}{S_{i, t}}+\mu_{i}+\varepsilon_{i, t},
$$

ahol $i t p_{t-1}$ az intertemporális preferenciákat leíró diszkonttöbblet trendjét jelöli.

A modellek segítségével szeretnénk megmutatni, hogy az intertemporális diszkonttöbblet növekedése a vállalatok tőkekeresletét csökkenti, ami arra utal, hogy a befektetők rövid távú érdekeinek előtérbe helyezése a tőkeköltség csatornán keresztül beruházások elutasításához vagy elhalasztásához vezet, és ezzel értéket rombol a vállalatok számára. A befektetői rövid távú érdekek kiszolgálása a hosszú távú tulajdonosi értékteremtés ellenében hat.

A 3. táblázatban a hozamelvárások és a tőkekereslet kapcsolatát vizsgáljuk meg. A becsléshez szükséges adatok a vizsgált minta tekintetében 527 vállalatra voltak elérhetőek és 12 üzleti évet tudtunk megvizsgálni a késleltetések miatt. A modelleket 
„within” transzformációval becsültük meg. A táblázatban a Newey-West standard hibákat közöljük. A C1 modellt a (5) egyenlet alapján, a C2 modellt a (6) egyenlet alapján, míg a C3 modellt a (7) egyenlet alapján becsültük meg.

A C1 modellben látható, hogy a sajáttőke-költségének 1 százalékos növekedése a vállalatok tőkekeresletét 0,1 százalékkal csökkenti. Így megfigyelhető a fordított arányosság a tőkekereslet és a sajáttőke-költsége között. Nem meglepő eredmény továbbá, hogy a tőkeintenzitás növekedése a tőkekeresletet növeli. A C2 modellben $x_{t-1}$ változó az intertemporális preferenciákat leíró diszkontfaktor trendjét jelöli. Míg 2009 előtt $x_{t-1}$ értéke 1 felett van, addig 2009-tól az érték 1 alá kerül, ami a befektetői rövid távú érdekek előtérbe kerülését jelzi. Az intertemporális preferenciákat leíró diszkontfaktor trendjéhez tartozó pozitív paraméter arra utal, hogy a befektetők rövid távú érdekeinek előtérbe kerülése a vállalatok tőkekeresletének csökkenését vetíti előre.

A C3 modellben ugyanerre a következtetésre juthatunk, ha az intertemporális diszkonttöbblet trendjének késleltetett értékével egészítjük ki a modellt. Az itp $p_{t-1}$ változó negatív paramétere arra utal, hogy az intertemporális diszkonttöbblet növekedése a tőkeköltség csatornán keresztül csökkentette a vállalatok tőkekeresletét. Az intertemporális diszkonttöbblet 1 százalékos növekedése a tőkekeresletet 0,048 százalékkal csökkenti.

3. táblázat

A hozamelvárások és a tőkekereslet kapcsolata

\begin{tabular}{|c|c|c|c|}
\hline$I_{i, t} / S_{i, t}$ & C1 & C2 & C3 \\
\hline$x_{t-1}$ & & $\begin{array}{l}0,049^{* * *} \\
(0,006)\end{array}$ & \\
\hline $\operatorname{itp}_{\mathrm{t}-1}$ & & & $\begin{array}{r}-0,048^{* *} \\
(0,005)\end{array}$ \\
\hline $\mathrm{COE}_{\mathrm{i}, \mathrm{t}-1}$ & $\begin{array}{c}-0,100^{* * *} \\
(0,038)\end{array}$ & $\begin{array}{c}-0,187^{* * *} \\
(0,038)\end{array}$ & $\begin{array}{r}-0,186^{* *} \\
(0,038)\end{array}$ \\
\hline $\mathrm{K}_{\mathrm{i}, \mathrm{t}} / \mathrm{S}_{\mathrm{i}, \mathrm{t}}$ & $\begin{array}{l}0,092^{* * *} \\
(0,006)\end{array}$ & $\begin{array}{l}0,092^{* * *} \\
(0,006)\end{array}$ & $\begin{array}{l}0,092^{* * *} \\
(0,006)\end{array}$ \\
\hline $\mathrm{R}^{2}$ & 0,118 & 0,131 & 0,131 \\
\hline Korrigált $\mathrm{R}^{2}$ & 0,037 & 0,052 & 0,052 \\
\hline Wooldridge próba: $p$-érték & 0,000 & 0,000 & 0,000 \\
\hline Megfigyelések száma & 6324 & 6324 & 6324 \\
\hline Vállalatok száma & 527 & 527 & 527 \\
\hline Üzleti évek száma & 12 & 12 & 12 \\
\hline
\end{tabular}


Az intertemporális preferenciák és a tőkekereslet kapcsolatát vizsgálva jól látható, hogy az implicit intertemporális diszkonttöbblet növekedése a tőkeköltség csatornán keresztül a tőkekereslet csökkenését eredményezi. A rövid távú befektetői érdekek kiszolgálása pozitív nettó jelenértékú beruházások elutasításához vagy elhalasztásához vezet, ezért tulajdonosi értéket rombol.

A modellek alapján ezen felül azt is láthatjuk, hogy a sajáttőke-költség csökkenése a tőkekereslet növekedését jelzi előre. Ahogy azt a 2. ábrán megmutattuk 2009es beruházási sokkot követően a vizsgált mintában a monetáris politikai lazítások hatása csak 2014-re csökkentette érdemben a sajáttőke-költségét, annak ellenére, hogy a kamatok csökkentése már az eurozóna adósságválságának lecsengésével párhuzamosan 2011-ben elkezdődött. Ez arra utal, hogy a válságot követő tőkepiaci folyamatok késleltethették a monetáris politika válságkezelő intézkedéseinek beruházásélénkítő hatását. Ezen felül az intertemporális diszkonttöbblet növekedése is a monetáris lazítások ellenében hatott.

\section{Következtetések}

A kutatás során megmutattuk, hogy az implicit, intertemporális diszkonttöbblet a 2004-2016-ig terjedő időszakban növekedett. 2008 előtt az intertemporális preferenciákat leíró diszkontfaktor értéke 1 felett volt, ezt követően 1 alá került. Míg 2008 előtt a befektetőket hosszú távú szemléletmód jellemezte, addig a válságot követően a befektetők a rövid távú érdekeit helyezik előtérbe. A befektetői hozamelvárások és a tőkeköltség közötti különbség megnövekedett. A válságot követően a befektetők nehezebben cserélik el a jelenbeli jövedelmüket egy jövőbeli hozamígéretre. Ha az implicit, intertemporális diszkonttöbblet beépül a vállalatok tőkeköltségébe, akkor az a tőkekeresletet csökkenti és pozitív nettó jelenértékű beruházások elutasításához vagy elhalasztásához vezet. Ezzel a tulajdonosi hosszú távú értékteremtési törekvéseket a beruházási restrikción keresztül háttérbe szorítja. A sajáttőke-költség és a tőkekereslet kapcsolatának vizsgálata olyan makroszintű sokkok hatásaira is rávilágít, mint a recesszió, a kamatkörnyezet változása, vagy a tőkekockázati prémium változása a tőkepiacokon. A vizsgált mintában 2014-ben látható egy jelentős csökkenés a sajáttőke-költségében, amely a kamatok csökkenésének és a tőkekockázati prémium változásának köszönhető. Ez arra utal, hogy sajáttőke-költség változásait és az intertemporális diszkonttöbblet növekedését tekintve a válságot követő tőkepiaci folyamatok késleltethették a monetáris politikai lazítások tőkekereslet élénkítő hatását. 


\section{Felhasznált irodalom}

Asker, J. - Farre-Mensa, J. - Ljungqvist, A. (2014): Corporate Investment and Stock Market Listing: A Puzzle? Review of Financial Studies, 28(2): 342-390. http://doi.org/10.1093/ $\mathrm{rfs} / \mathrm{hhu077}$

Blundell-Wignall, A. - Roulet, C. (2013): Long-term investment, the cost of capital and the dividend and buyback puzzle. OECD Journal: Financial Market Trends, 2013(1): 39-52. http://doi.org/10.1787/fmt-2013-5k41z8t05l8s

Bölcskei Vanda (2009): Az intertemporális döntések viselkedési közgazdaságtani modelljeinek áttekintése. Közgazdasági Szemle, 56(november): 1025-1040.

Campbell, J.L. - Dhaliwal, D.S. - Schwartz, W.C. (2012): Financing Constraints and the Cost of Capital: Evidence from the Funding of Corporate Pension Plans. Review of Financial Studies, 25(3): 868-912 http://doi.org/10.1093/rfs/hhr119

Damodaran, A. (2019): Equity Risk Premiums (ERP): Determinants, Estimation and Implications - The 2019 Edition. http://doi.org/10.2139/ssrn.3378246

Davies, R. - Haldane, A. G. - Nielsen, M. - Pezzini, S. (2014): Measuring the costs of short-termism. Journal of Financial Stability, 12(June): 16-25. http://doi.org/10.1016/j. jfs.2013.07.002

Dixon, W.J. (1960): Simplified Estimation from Censored Normal Samples. The Annals of Mathematical Statistics, 31(2): 385-391. http://doi.org/10.1214/aoms/1177705900

Duchin, R. - Ozbas, O. - Sensoy, B.A. (2010): Costly external finance, corporate investment, and the subprime mortgage credit crisis. Journal of Financial Economics, 97(3): 418-435. http://doi.org/10.1016/j.jfineco.2009.12.008

Favaro, K. (2014): Long-Termism Is Just as Bad as Short-Termism. Harvard Business Review, September 25.

Fazzari, S. - Hubbard, R. G. - Petersen, B. (1988): Financing Constraints and Corporate Investment. Brookings Papers on Economic Activity, 1988(1): 141-206. http://doi. org/10.2307/2534426

Feldman, N. - Kawano, L. - Patel, E. - Rao, N. - Stevens, M. (2018): The Long and Short of It: Do Public and Private Firms Invest Differently? Finance and Economics Discussion Series, 2018-068. Washington: Board of Governors of the Federal Reserve System. http://doi. org/10.17016/feds.2018.068

Hackbarth, D. - Rivera, A. - Wong T.Y. (2018): Optimal Short-Termism. ECGI Finance Working Paper no. 546/2018. European Corporate Governance Institute. http://people.bu.edu/ dhackbar/HRW-2018.pdf. Letöltés ideje: 2020. május 8. 
Hastings, C. - Mosteller, F. - Tukey, J. W. - Winsor, C.P. (1947): Low Moments for Small Samples: A Comparative Study of Order Statistics. The Annals of Mathematical Statistics, 18(3): 413-426. http://doi.org/10.1214/aoms/1177730388

Janssens, W. - Kramer, B. - Swart, L. (2017): Be patient when measuring hyperbolic discounting: Stationarity, time consistency and time invariance in a field experiment. Journal of Development Economics, 126(May): 77-90. https://doi.org/10.1016/j. jdeveco.2016.12.011

Laibson, D. (1997): Golden Eggs and Hyperbolic Discounting. The Quarterly Journal of Economics, 112(2): 443-478. https://doi.org/10.1162/003355397555253

Mankins, M. - Harris, K. - Harding, D. (2017): Strategy in the Age of Superabundant Capital. Harvard Business Review, March-April.

Martin, R.L. (2015): Yes, Short-Termism Really Is a Problem. Harvard Business Review, October.

Mauboussin, M.J. - Rappaport, A. (2016): Reclaiming the Idea of Shareholder Value. Harvard Business Review, July.

Miles, D. (1993): Testing for Short Termism in the UK Stock Market. The Economic Journal, 103(421): 1379-1396. https://doi.org/10.2307/2234472

Neszveda Gábor - Dezső Linda (2012): A kvázi- és általánositott hiperbolikus diszkontálás hosszú távon. Szigma, 43(3-4): 163-177.

Phelps, E.S. - Pollak, R.A. (1968): On Second-Best National Saving and GameEquilibrium Growth. The Review of Economic Studies, 35(2): 185-199. https://doi. $\operatorname{org} / 10.2307 / 2296547$

Rasmusen, E.B. (2008): Some Common Confusions About Hyperbolic Discounting. SSRN Electronic Journal. https://doi.org/10.2139/ssrn.1091392

Simmons-Süer, B. (2016): Cost of capital and US investment: Does financing matter after all? The Quarterly Review of Economics and Finance, 60(May): 86-93. https://doi. org/10.1016/j.qref.2015.11.008

Simmons-Süer, B. (2018): How relevant is capital structure for aggregate investment? A regime-switching approach. International Review of Economics \& Finance, 53(January): 109-117. https://doi.org/10.1016/j.iref.2017.10.002

Stein, J. (1989): Efficient Capital Markets, Inefficient Firms: A Model of Myopic Corporate Behavior. Quarterly Journal of Economics, 104(November): 655-669. https://doi. org/10.2307/2937861 
Summers, L.H. (2017): Is Corporate Short-Termism Really a Problem? The Jury's Still Out. Harvard Business Review, February.

Tukey, J.W. (1977): Exploratory Data Analysis. Addison-Wesley.

Vörös, J. (2020): Production dynamics in case of organizational learning. Mimeo, University of Pécs.

White, H. (1980): A Heteroskedasticity-Consistent Covariance Matrix Estimator and a Direct Test for Heteroskedasticity. Econometrica, 48(4): 817-838. http://doi.org/10.2307/1912934

Wickens, M.R. (1982): The Efficient Estimation of Econometric Models with Rational Expectations. The Review of Economic Studies, 49(1): 55-67. https://doi. org $/ 10.2307 / 2297140$ 